\title{
Metode Analisis Model Peluruhan Bahan Radioaktif dengan Menggunakan Sensor Gaya dan Rekaman Video
}

\author{
Yosephine Novita Apriati, Ign Edi Santosa \\ Program Studi Pendidikan Fisika, Universitas Sanata Dharma \\ Paingan, Maguwoharjo, Depok, Sleman, Yogyakarta \\ Email : yosephinetha@gmail.com, edi@dosen.usd.ac.id.
}

\begin{abstract}
The number of decayed radioactive materials each time leads to the exponential law. Process of the decaying radioactive materials can't easily be seen, so it can be modeled using the flow of water from a vertical column through a pipe. A force sensor can be used to collect data that showing the decline of water surface in a column. A pipe inserted in a tube contain of water is suspended in the force sensor. The force sensor is connected to a computer. The output shows an exponential graph identical to the exponential law of radioactive decay graph. Another method to collect data for height of water surface each time is using a camera. A video of the declining water surface can be analyzed using video analyzer from Logger Pro. The graph result is also identical with the radioactive decay graph. From both of the methods the decay constant can be found. By using a pipe with radius $(3,7 \pm 0,5) \times 10^{-1} \mathrm{~cm}$ the decay constant for force sensor and camera methods consequently are $(7,8 \pm 0,1) \times 10^{-2} s^{-1}$ and $(7,3 \pm 0,3) \times 10^{-2} s^{-1}$. The method using a video record that being analyzed by video analyzer is easier to be done because the tools are easy to get. A camera can even be found in a cellphone and an application providing video analysis also can easily be downloaded from the internet.
\end{abstract}

Key words : Radioactive decay models, force sensor, video recording, video analyzer, Logger Pro.

Abstrak: Jumlah bahan radioaktif yang meluruh setiap waktu mengikuti grafik eksponensial. Peristiwa peluruhan bahan radioaktif yang sulit diamati dapat dimodelkan dengan menggunakan peristiwa penurunan air dalam suatu tabung yang diberi pipa keluaran. Salah satu metode pencatatan data peristiwa penurunan tersebut dilakukan dengan menggunakan sensor gaya. Sebuah tabung berisi air yang diberi pipa keluaran digantungkan pada sebuah sensor gaya yang dihubungkan dengan komputer. Hasil grafik berat air setiap waktu menunjukkan grafik eksponensial yang identik dengan grafik peluruhan bahan radioaktif. Metode lain yang dapat dilakukan adalah dengan merekam ketinggian air setiap waktu di dalam tabung menggunakan kamera. Hasil rekaman dianalisis dengan menggunakan aplikasi video analyzer dari software Logger Pro. Hasil analisis menunjukkan ketinggian air setiap waktu mengikuti grafik peluruhan bahan radioaktif. Dengan menggunakan pipa keluaran berukuran $(3,7 \pm 0,5) \times 10^{-1} \mathrm{~cm}$ diperoleh nilai konstanta peluruhan dengan metode sensor gaya dan metode rekaman secara berturut-turut adalah $(7,8 \pm 0,1) \times 10^{-2} s^{-1}$ dan $(7,3 \pm 0,3) \times 10^{-2} s^{-1}$. Metode dengan rekaman video yang dianalisis dengan aplikasi video analyzer dari software Logger Pro lebih mudah dilakukan karena hanya membutuhkan sebuah kamera perekam. Aplikasi video analyzer juga mudah diunduh di internet.

Kata kunci : model peluruhan bahan radioaktif, sensor gaya, rekaman, video analyzer, Logger Pro.

\section{PENDAHULUAN}

Bahan radioaktif adalah bahan yang memiliki inti yang tidak stabil. Untuk membentuk inti yang stabil, bahan radioaktif meluruh dengan mengemisikan sinar radioaktif (Krane. 1988). Setiap bahan radioaktif meluruh mengikuti konstanta peluruhan $\lambda$ masing - masing. Nilai $\lambda$ ini menentukan waktu paruh setiap bahan radioaktif. Pada beberapa bahan, waktu paruhnya sangat lama sehingga peluruhan bahan radioaktif sulit teramati. Sebagai bahan pembelajaran, 
peluruhan bahan radioaktif ini dapat dimodelkan. Peristiwa peluruhan bahan radioaktif dapat dimodelkan dengan menggunakan peristiwa penurunan ketinggian air dalam tabung yang dihubungkan dengan pipa keluaran.

Beberapa penelitian telah dilakukan untuk mengetahui nilai $\lambda$ dari model peluruhan bahan radioaktif. Data yang diperlukan adalah data ketinggian air setiap waktu. Pencatatan data ketinggian air dalam kolom tabung setiap waktu pernah dilakukan dengan menggunakan sensor gaya yang digantungi tabung berisi air yang dihubungkan dengan pipa keluaran (Fairman, S.J dkk. 2003). Grafik berat air setiap waktu menunjukkan grafik yang identik dengan grafik peluruhan bahan radioaktif. Sensor gaya yang digunakan adalah sensor keluaran Vernier.

Pencatatan posisi setiap waktu dapat dilakukan dengan aplikasi video analyzer. Perekaman proses jatuhnya magnet di dalam suatu tabung nonmagnetic digunakan untuk menentukan nilai koefisien magnetic-braking. Untuk memperoleh grafik posisi terhadap waktu pada peristiwa jatuhnya magnet dalam tabung nonmagnetik, rekaman dianalisis dengan menggunakan aplikasi komputer yang dapat menganalisis video (video analyzer) (Bolivar dan Palacios. 2012). Cara yang sama juga pernah dilakukan untuk mengukur kecepatan terminal dan gaya gesek udara yang bekerja pada kertas cupcake. (Becker, Klein, dan Kuhn. 2016). Aplikasi video analyzer memungkinkan memperoleh data ketinggian air setiap waktu untuk suatu peristiwa yang terekam. Dengan demikian penurunan ketinggian air dalam kolom tabung yang dihubungkan dengan pipa keluaran juga dapat diamati dengan menggunakan kamera. Hasil rekaman video dapat dianalisis menggunakan aplikasi video analyzer untuk mendapatkan data posisi ketinggian air setiap waktu.

\section{METODE PENELITIAN}

Pada peluruhan bahan radiokatif, banyaknya bahan radioaktif pada waktu $t$ dapat dinyatakan oleh :

$$
N(t)=N_{0} \exp (-\lambda t)
$$

dengan $N_{o}$ adalah jumlah bahan radioaktif pada saat $t=0$,

$\square \square$ adalah konstanta peluruhan

Waktu paruh adalah waktu yang dibutuhkan suatu bahan radioaktif untuk meluruhkan separuh bagiannya. Jika pada saat $t=0$ jumlah bahan radioaktif adalah $N_{o}$, maka pada saat $t_{1 / 2}$ (waktu paruh) jumlah bahan radioaktif akan menjadi $N=N_{0} / 2$ (Krane, 1988). Waktu paruh dapat diketahui dengan memasukkan nilai $N=N_{0} / 2$ ke persamaan (1). Sehingga hasil penyelesaiannya akan diberikan oleh

$$
t_{1 / 2}=\frac{\ln 2}{\lambda}
$$

Peristiwa peluruhan bahan radioaktif dapat dimodelkan menggunakan penurunan air pada kolom tabung yang dihubungkan dengan pipa keluaran seperti ditunjukkan pada gambar 1 . Sebuah tabung dengan luas penampang $A$ dihubungkan dengan pipa keluaran yang memiliki panjang $L$ dan jari-jari $r$.

Laju aliran air di dalam pipa seperti pada gambar 1 mengikuti persamaan Poisoulle

$$
Q=\frac{\pi\left(P_{1}-P_{2}\right) r^{4}}{8 \eta L}
$$

dengan $\left(P_{1}-P_{2}\right)$ adalah perbedan tekanan diatara kedua ujung pipa, $\eta$ viskositas cairan.

Untuk air dengan ketinggian $h$ dan massa jenis $\rho$ perbedaan tekanan pada kedua ujung pipa mengikuti : 


$$
P_{1}-P_{2}=\rho g h
$$

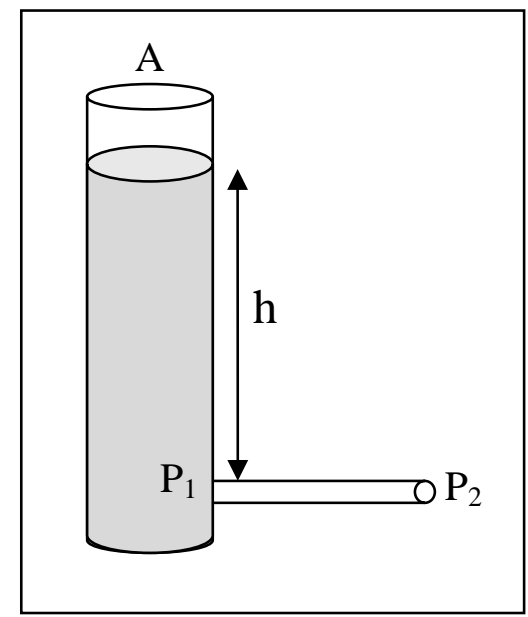

Gambar 4. Tabung yang dihubungkan dengan pipa keluaran

Dengan memasukkan persamaan (4) ke dalam persamaan (3) dapat diperoleh

$$
Q=\frac{\pi \rho g h r^{4}}{8 \eta L}
$$

Laju aliran air ditandai dengan penurunan ketinggian air di dalam kolom tabung mengikuti persamaan (6).

$$
Q=-A \frac{d h}{d t}
$$

Dari persamaan (5) dan persamaan (6) dapat diperoleh

$$
\frac{d h}{d t}=-\left(\frac{\pi \rho g r^{4}}{A 8 \eta L}\right) h
$$

atau

$$
\frac{d h}{d t}=-\lambda^{\prime} h
$$

dengan

$$
\lambda^{\prime}=\frac{\pi \rho g r^{4}}{A 8 \eta L}
$$

Penyelesaian dari persamaan (8) adalah

$$
h(t)=h_{0} \exp \left(-\lambda^{\prime} t\right)
$$

\subsection{Metode Sensor Gaya}

Konstanta peluruhan $\lambda$ dapat diperoleh dengan menggunakan setup percobaan seperti pada gambar 2. Tabung berisi air dengan pipa keluaran digantungkan pada sensor gaya. Interface LabPro digunakan untuk menghubungkan sensor dengan laptop yang dilengkapi software 
LoggerPro. Sensor gaya mencatat berat air di dalam tabung selama air mengalir keluar dari tabung,

Berat air tergantung dengan banyaknya air di dalam tabung. Berat air $W$ pada saat $t$ mengikuti persamaan:

$$
W(t)=g \rho A h(t)
$$

Dengan menggunakan persamaan (11) dan persamaan (10), dapat diperoleh persamaan

$$
W(t)=W_{0} \exp \left(-\lambda^{\prime} t\right)
$$

dengan $W_{0}$ adalah berat air mula-mula.

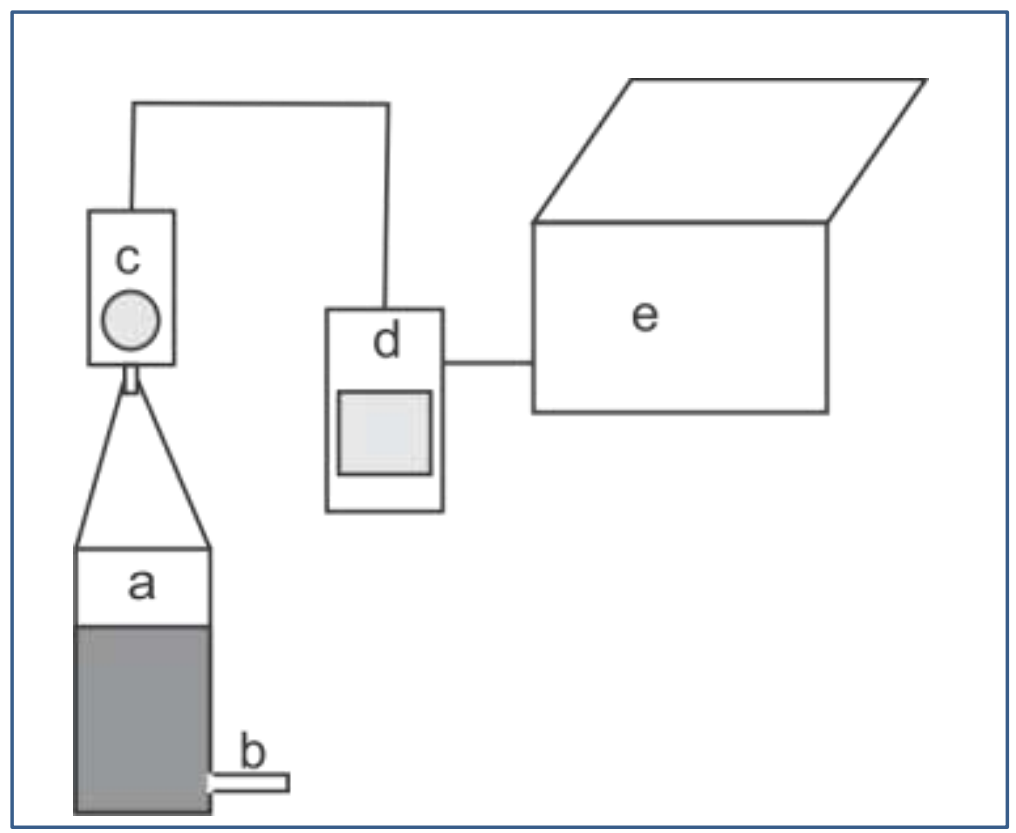

Gambar 5. Susunan peralatan metode sensor gaya dengan a) tabung, b) pipa keluaran, c) sensor gaya, d) Lab pro, dan e) Laptop

Dengan memperhitungkann berat tabung dan pipa keluaran $\left(W_{b}\right)$ serta persamaan (12), berat yang tercatat pada sensor gaya $W^{\prime}$ dapat dituliskan menjadi

$$
W^{\prime}(t)=W_{0} \exp \left(-\lambda^{\prime} t\right)+W_{b}
$$

Nilai konstanta peluruhan $\square$ ' dapat diperoleh dari fiting pada grafik berat yang teracatat setiap waktu dengan persamaan (12).

\subsection{Metode Analisis Rekaman Video}

Pencatan data ketinggian air dalam kolom tabung setiap waktu dilakukan secara langsung dengan merekam penurunan ketinggian air. Ketinggian air di dalam tabungdirekam selama air mengalir dari pipa keluaran, Rekaman video dianalisis dengan menggunakan aplikasi video analyzer pada software Logger Pro. Untuk mendapatkan nilai $\lambda$, grafik ketinggian air setiap waktu difit dengan menggunakan persamaan (10). 


\section{HASIL DAN PEMBAHASAN}

\subsection{Hasil Metode dengan Sensor Gaya}

Tabung dihubungkan dengan pipa keluaran berukuran jari-jari $(3,7 \pm 0,5) \times 10^{-1} \mathrm{~cm}$ dan digantungkan ke sensor gaya. Ke dalam tabung diisikan sejumlah air, kemudian air dibiarkan mengalir melalui pipa keluaran. Berat air akan mengalami pengurangan setiap waktu. Hasil pencatatan data dengan menggunakan sensor gaya ditampilkan pada gambar 3 .

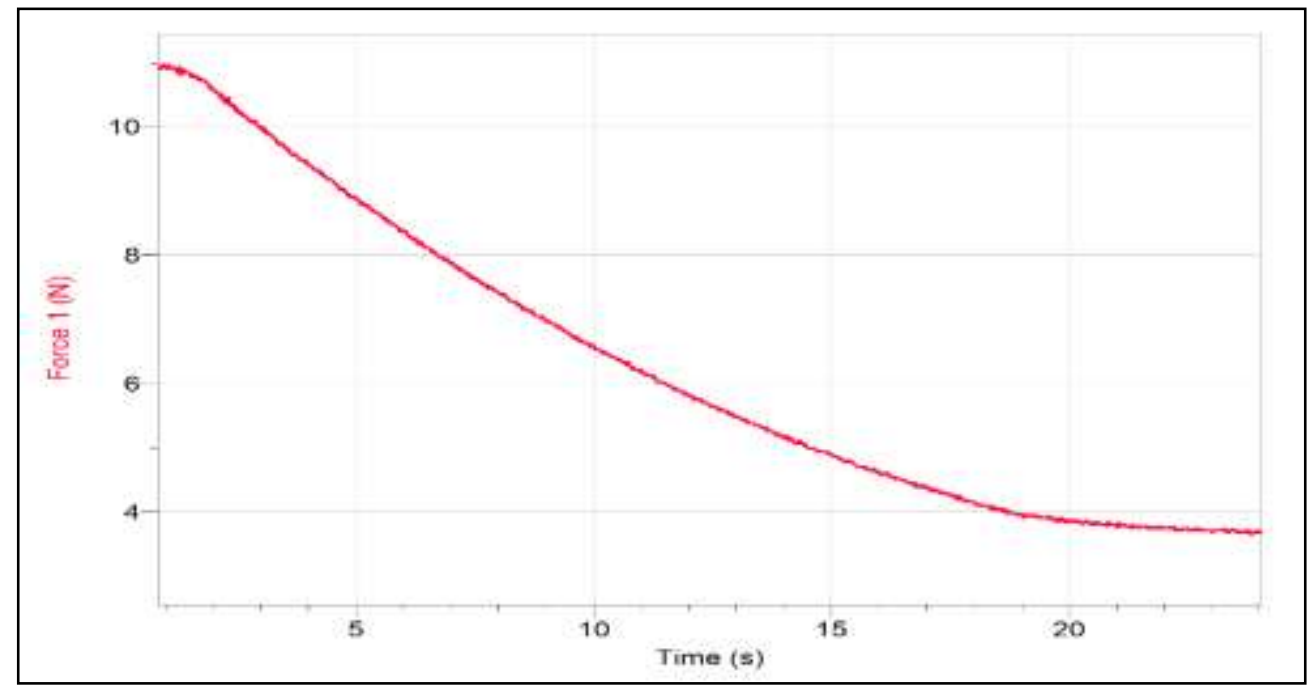

Gambar 6. Grafik berat air setiap waktu pada pipa keluaran dengan panjang $10 \mathrm{~cm}$ dan berjari-jari $(3,7 \pm 0,5) \times 10^{-1} \mathrm{~cm}$

Grafik difit dengan persamaan (6). Sehingga diperoleh hasil fitting yang ditunjukkan pada gambar 4.

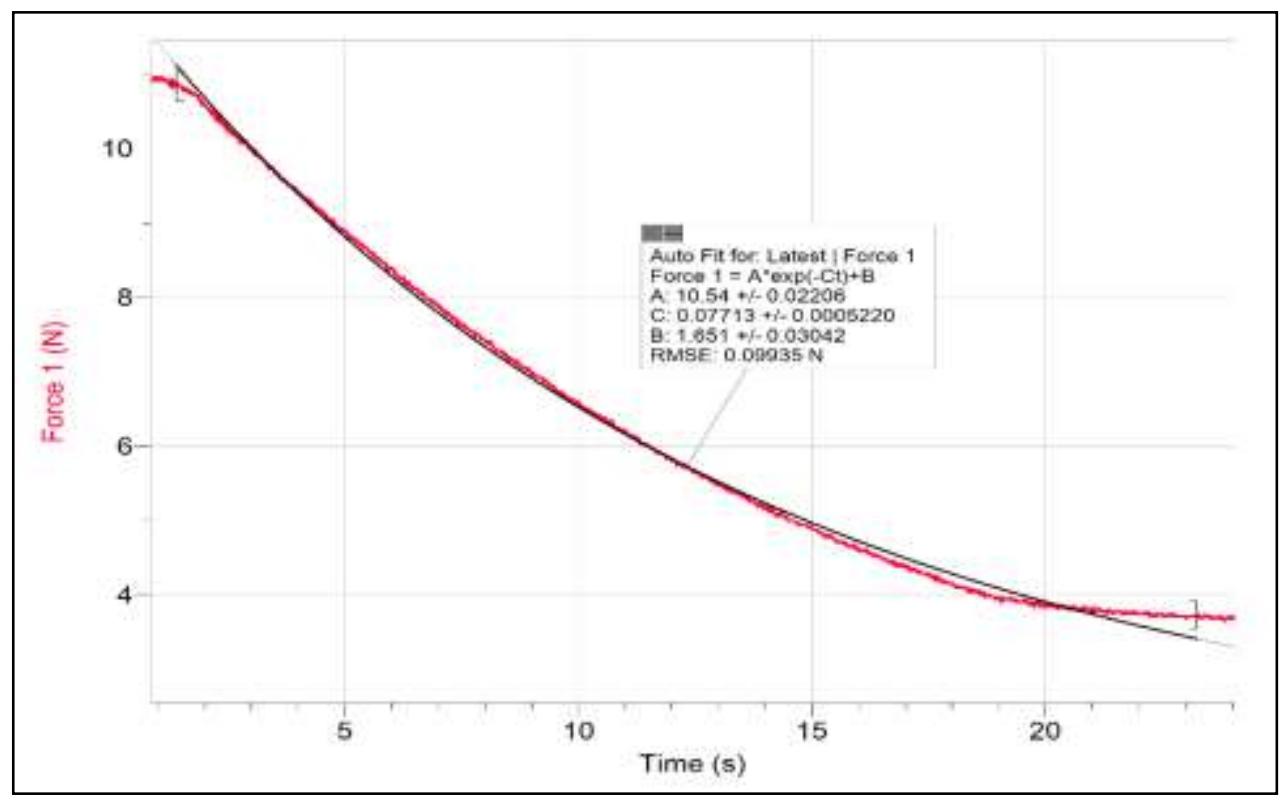

Gambar 7. Fitting grafik berat air setiap waktu pada tabung dengan pipa keluaran berukuran panjang $10 \mathrm{~cm}$ dan berjari-jari $(3,7 \pm 0,5) \times 10^{-1} \mathrm{~cm}$ 
Dari hasil fitting grafik diperoleh nilai $\lambda$ adalah $(7,8 \pm 0,1) \times 10^{-2} s^{-1}$. Dari hasil ini dapat dikatakan bahwa metode pencatatan data dengan menggunakan sensor gaya berhasil membentuk grafik yang sesuai dengan grafik peluruhan bahan radioaktif. Dengan demikian nilai $\square \square$ yang diperoleh dapat digunakan untuk menghitung waktu paruh. Waktu paruh yang dihitung dengan menggunakan persamaan (2) diperoleh $(8,9 \pm 0,1) \mathrm{s}$.

Sensor gaya yang digunakan adalah sensor buatan Vernier dari Amerika yang harganya cukup mahal. Selain itu, untuk pembelajaran sederhana sensor semacam ini tidak banyak tersedia.

Oleh karena itu perlu dibuat metode lain yang mampu mencatat data berupa ketinggian air setiap waktu akan tetapi mempergunakan peralatan yang lebih sederhana.

\subsection{Hasil Metode dengan Analisis Rekaman Video}

Sama seperti metode sebelumnya, sebuah tabung yang dihubungkan dengan pipa keluaran berukuran $(3,7 \pm 0,5) \times 10^{-1} \mathrm{~cm}$ diisi sejumlah air kemudian air dibiarkan mengalir melalui pipa keluaran. Akan tetapi, penurunan ketinggian air setiap waktu direkam dengan menggunakan kamera. Hasil rekaman berupa video dianalisis menggunakan aplikasi video analyzer dari software Logger Pro. Video dianalisis dengan memberi titik pada posisi ketinggian air di dalam video. Hasil yang diperoleh adalah grafik ketinggian air setiap waktu yang ditampilkan pada gambar 5.

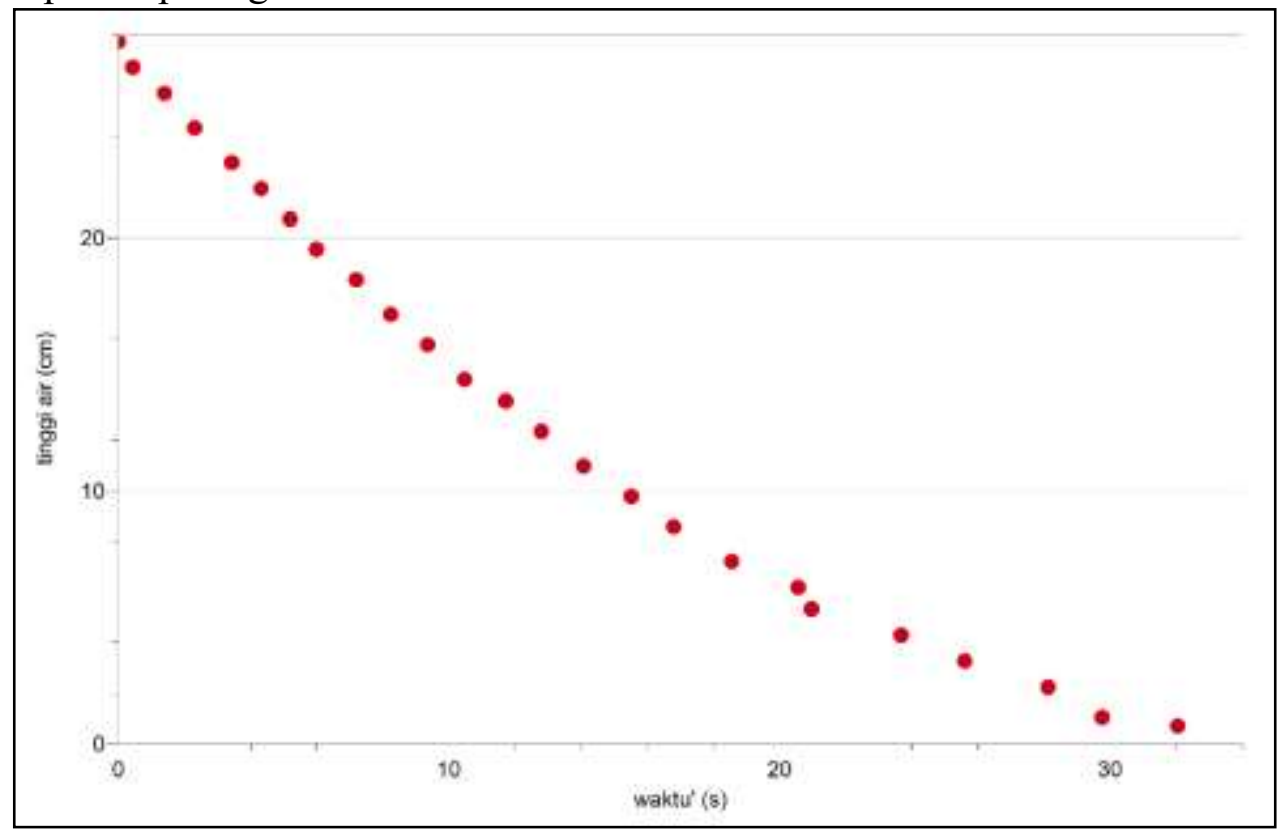

Gambar 8. Grafik ketinggian air pada tabung setiap waktu hasil analisis video pada pipa keluaran dengan panjang $10 \mathrm{~cm}$ dan berjari-jari $(3,7 \pm 0,5) \times 10^{-1} \mathrm{~cm}$

Grafik pada gambar 5 difit dengan menggunakan persamaan (6) sehingga diperoleh grafik hasil fitting yang ditampilkan pada gambar 6 . 


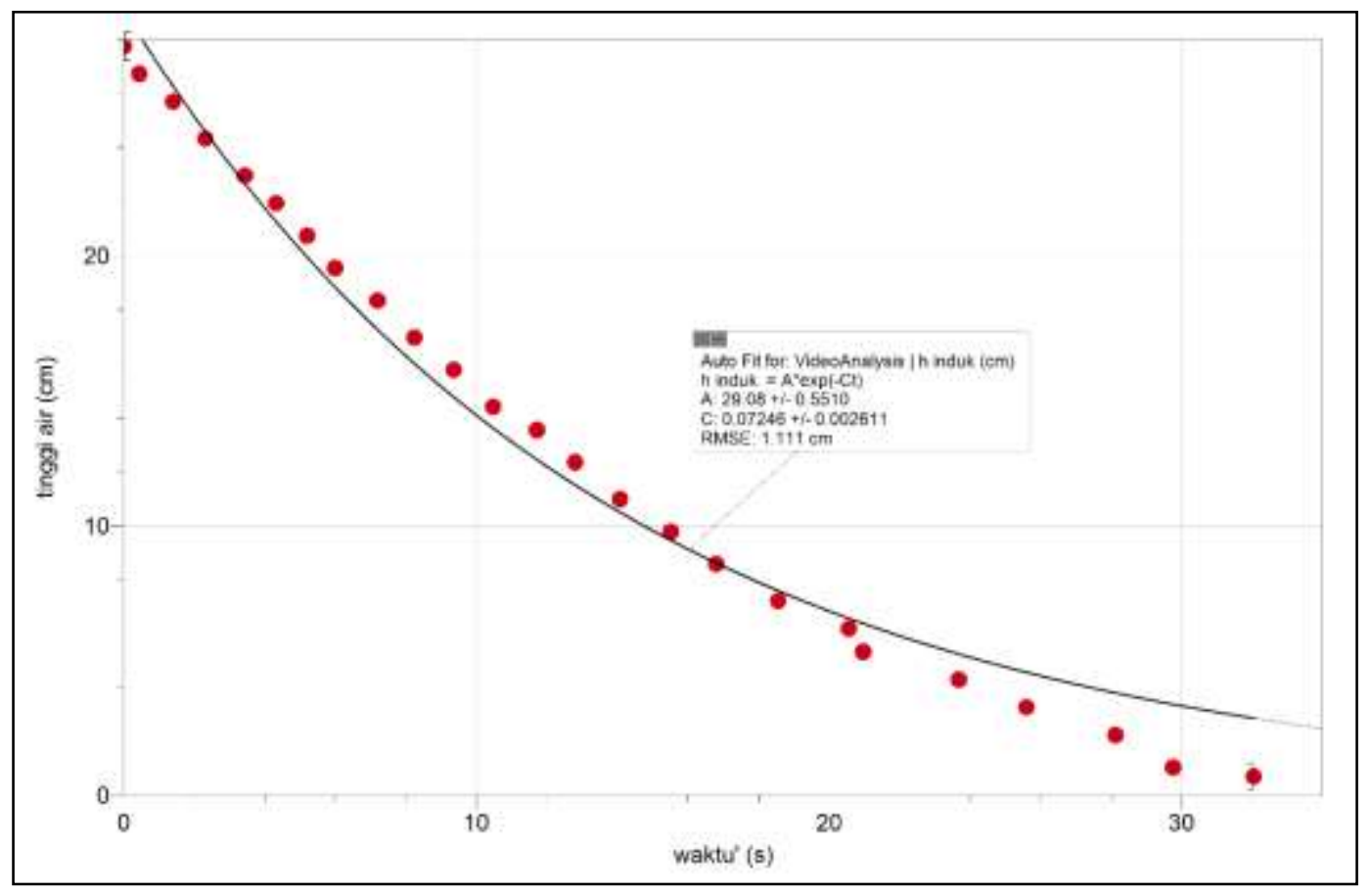

Gambar 9. Fitting grafik ketinggian air setiap waktu pada tabung dengan pipa keluaran berukuran panjang $10 \mathrm{~cm}$ dan berjari-jari $(3,7 \pm 0,5) \times 10^{-1} \mathrm{~cm}$

Dari grafik pada gambar 6 diperoleh koefisien peluruhan $\lambda$ sebesar $(7,3 \pm 0,3) \times 10^{-2} s^{-1}$. Dengan menggunakan persamaan (2) dapat dihitung waktu paruh untuk hasil data dengan metode rekaman video ini adalah $(9,5 \pm 0,4) \mathrm{s}$.

\subsection{Pembahasan}

Bahan radioaktif yang meluruh tidak dapat diamati secara langsung. Oleh karena itu di dalam pembelajaran, peluruhan bahan radioaktif ini dapat dimodelkan. Peluruhan bahan radioaktif dimodelkan dengan menggunakan penurunan ketinggian air di dalam kolom tabung yang dihubungkan dengan pipa keluaran. Air akan keluar melalui pipa keluaran dengan debit mengikuti persamaan (5) dan (6). Dengan memperhitungkan luas penampang tabung dapat diperoleh ketinggian air setiap saat mengikuti persamaan (10). Selanjutnya berat air di dalam tabung juga berubah terhadap waktu mengikuti persamaan (12). Dari persamaan (10) dan (12) terlihat bahwa ketinggian air dan berat air di dalam tabung mengikuti penurunan secara eksponensial seperti halnya peluruhan bahan radiokatif. Dengan demikian dapat berat air dan ketinggian air setiap saat dapat digunakan untuk memodelkan peluruhan bahan radioaktif.

Untuk membuktikan peristiwa tersebut diperlukan data berupa ketinggian air ataupun berat air setiap waktu. Pengukuran berat dapat dilakukan dengan menggunakan sensor gaya (Fairman, S.J dkk. 2003). Tabung berisi air yang dihubungkan dengan pipa keluaran digantungkan ke sensor gaya yang dihubungkan dengan interface LabPro. Ketinggian air dalam kolom dapat diukur secara langsung menggunakan kamera Hasil rekaman yang berupa video kemudian dianalisis dengan menggunakan aplikasi video analyzer dari software Logger Pro.

Dari kedua metode diperoleh grafik eksponensial. Metode pertama menghasilkan grafik eksponensial berat air setiap waktu sedangkan metode kedua menghasilkan grafik eksponensial ketinggian air setiap waktu. Dari masing - masing grafik dapat diperoleh nilai koefisien peluruhan $\square \square$ dan waktu paruh yang ditampilkan pada tabel 1 . 
Tabel 1. Hasil data $\square \square \square s^{-1}$ ) dan $t_{1 / 2}(s)$ dari metode sensor gaya dan metode rekaman video pada pipa keluaran dengan panjang $10 \mathrm{~cm}$ dan berjari-jari $(3,7 \pm 0,5) \times 10^{-1} \mathrm{~cm}$

\begin{tabular}{cccc}
\hline No. & Metode & $\left.\square \square \square s^{-1}\right)$ & $t_{1 / 2}(s)$ \\
\hline 1 & Sensor Gaya & $(7,8 \pm 0,1) \times 10^{-2}$ & $8,9 \pm 0,1$ \\
2 & Rekaman Video & $(7,3 \pm 0,3) \times 10^{-2}$ & $9,5 \pm 0,4$ \\
\hline
\end{tabular}

Dari kedua metode dengan menggunakan diperoleh nilai $\lambda$ yang hampir sama. Akan tetapi metode dengan menggunakan rekaman video lebih mudah dilakukan. Peralatan yang diperlukan pun tidak sulit diperoleh. Untuk mencatat data hanya diperlukan sebuah kamera. Sebuah kamera yang dapat merekam video bahkan dapat diperoleh dari handphone. Untuk analisis video, aplikasi video analyzer banyak tersedia dan dapat diunduh secara gratis di internet. Sebaliknya pengukuran berat di atas memerlukan alat yang relatif mahal yaitu sensor dan interfacenya.

Pengukuran ketinggian air di dalam tabung dapat menunjukkan proses peluruhan secara langsung. Air terlihat berkurang secara jelas. Hal ini penting bagi pembelajaran. Dengan melihat secara langsung dan nyata diharapkan siswa dapat lebih memahami prosesnya. Siswa tidak hanya mahir menghitung nilai konstanta peluruhan dan waktu paro. Karena itu model peluruhan semacam ini dapat digunakan untuk menunjukkan peluruhan bahan radioaktif di dalam kelas. Selain itu, metode analisis menggunakan rekaman video juga dapat dimanfaatkan sebagai media praktikum lain yang membutuhkan data berupa posisi setiap waktu. Contohnya pada materi mengenai gerak seperti gerak lurus atau gerak parabola.

\section{KESIMPULAN}

Peluruhan bahan radioaktif dapat dimodelkan dengan peristiwa penurunan ketinggian air pada kolom tabung yang dihubungkan dengan pipa keluaran. Model ini dibuktikan dengan pengukuran koefisien peluruhan $\lambda$. Berdasarkan hasil data yang diperoleh, untuk pipa keluaran dengan panjang $10 \mathrm{~cm}$ dan berjari-jari $(3,7 \pm 0,5) \times 10^{-1} \mathrm{~cm}$ diperoleh nilai konstanta peluruhan dengan metode sensor gaya dan metode rekaman secara berturut-turut adalah $(7,8 \pm 0,1) \times 10^{-2} s^{-1}$ dan $(7,3 \pm 0,3) \times 10^{-2} s^{-1}$. Kedua metode menghasilkan nilai $\lambda$ yang saling mendekati. Sehingga dapat disimpulkan kedua metode dapat memberikan hasil yang relatif sama untuk pipa keluaran tertentu. Metode dengan menggunakan rekaman video lebih mudah dilakukan karena peralatan yang diperlukan lebih sederhana. Sebagai bahan pembelajaran di kelas, metode dengan rekaman video lebih cocok dipilih dengan mempertimbangkan peralatan yang diperlukan.

\section{SARAN}

Metode perekaman dan analisis video pada penurunan ketinggian air dalam kolom tabung dapat dimanfaatkan untuk menganalisis peristiwa lainnya yang membutuhkan data berupa posisi terhadap waktu.

\section{DAFTAR PUSTAKA}

Becker S, Klein P, Kuhn J. Video Analysis on Tablet Computer to Investigate Effects of Air Resistance. The Physics Teacher. vol 54. 2016.

Krane, Kenneth S. 1988. Introductory Nuclear Physics. John Wiley \& Sons : Singapore.

Molina-Bolivar J.A, Abella-Palacios A.J. Magnetic Braking : A Video Analysis. The Physics Teacher. vol 50. 2012. 
S. J. Fairman, J. A. Johnson, dan T. A. Walkiewicz. Fluid Flow with Logger Pro. The Physics Teacher. vol 41. 2003. pp. 345-350. 